\title{
A new species of the bee genus Ammobates LATREILLE, 1809 from sub-Saharan Africa (Hymenoptera: Apidae)
}

\author{
Michael KUHLMANN ${ }^{1}$ (D) \\ KuHLmann, M. (2021). A new species of the bee genus Ammobates Latrellle, 1809 from sub-Saharan Africa (Hymenoptera: Apidae). \\ Osmia, 9: 45-50. https://doi.org/10.47446/OSMIA9.6
}

\begin{abstract}
The cleptoparasitic bee Ammobates (Ammobates) roggeveldi n. sp. is described from a female specimen collected in western South Africa. This is only the second species of the genus recorded from sub-Saharan Africa.
\end{abstract}

Keywords $\mid$ Anthophila • Apoidea • taxonomy • Greater Cape Floristic Region • South Africa

Une nouvelle espèce d'abeille d'Afrique subsaharienne du genre Ammobates LATREILLE, 1809 (Hymenoptera : Apidae)

Résumé

Une nouvelle espèce du genre cleptoparasite Ammobates, Ammobates (Ammobates) roggeveldi n. sp., est décrite à partir d'un spécimen femelle collecté en Afrique du Sud occidentale. C'est seulement la deuxième espèce de ce genre rapportée pour l'Afrique subsaharienne.

Mots-clefs $\mid$ Anthophila $•$ Apoidea $•$ taxonomie $•$ région floristique de Greater Cape $•$ Afrique du Sud

Reçu • Received | 17 July 2021 || Accepté · Accepted|13 October 2021 || Publié (en ligne) • Published (online) | 15 October 2021 Reviewers | P. BOGUSCH • G. LEMOINE || http://zoobank.org/4DE4D398-78BF-48FE-B667-9E05B31A0761

\section{INTRODUCTION}

Ammobates LATREILLE, 1809 currently includes 50 species (ENGEL, 2009), mostly from the Palaearctic, and one each in the Oriental and Afrotropical regions (MICHENER, 2007). The genus is subdivided in three subgenera: Ammobates s. str. (41 species, known from Morocco through Europe and North Africa to southern India with a single species in South Africa and Namibia), Euphileremus POPOV, 1951 (six species ranging from the Canary Islands eastwards to Uzbekistan) and Xerammobates POPOV, 1951 (three species in Tunisia and Turkmenistan) (MICHENER, 2007; ENGEL, 2009).

During fieldwork in western South Africa, a new Ammobates species was discovered. The female was collected by sweep net and readily recognizable as undescribed in the field because it is completely black while in the only other sub-Saharan Ammobates species, A. auster EARDLEY, 1997, the metasoma and legs are at least partly orangish (EARDLEY \& BROTHERS, 1997). Because of its biogeographic significance herein the conspicuous second Ammobates species from sub-Saharan Africa and the southern hemisphere is described based on a female specimen collected in the Greater Cape Floristic Region (GCFR) of western South Africa (BORN et al., 2007; LINDER et al., 2010). The new species was found in Mountain Renosterveld vegetation (VAN DER MERWE et al., 2008) along a dry river bed in the northern extension of the HantamRoggeveld Centre of plant endemism (CLARK et al., 2011) south of Calvinia (Northern Cape Province), South Africa (figure 1).

\section{MATERIAL AND METHODS}

For morphology, the terminology of MICHENER (2007) was used. Puncture density is characterized by the relationship between puncture diameter (d) and the space between these punctures (i). Body length was measured from the vertex to the apex of the body. Images were taken with a
Keyence VHX-5000 Digital Microscope.

The holotype of the new species will be housed in the Iziko South African Museum, Cape Town, South Africa (SAMC).

' [MK] Zoological Museum, University of Kiel, Hegewischstraße 3, D-24105 Kiel, Germany•mkuhlmann@zoolmuseum.uni-kiel.de (D) https://orcid.org/0000-0003-3664-6922 • zoosank http://zoobank.org/B99AE0ED-FA89-4DFE-A658-1C8DF37F9FAB 


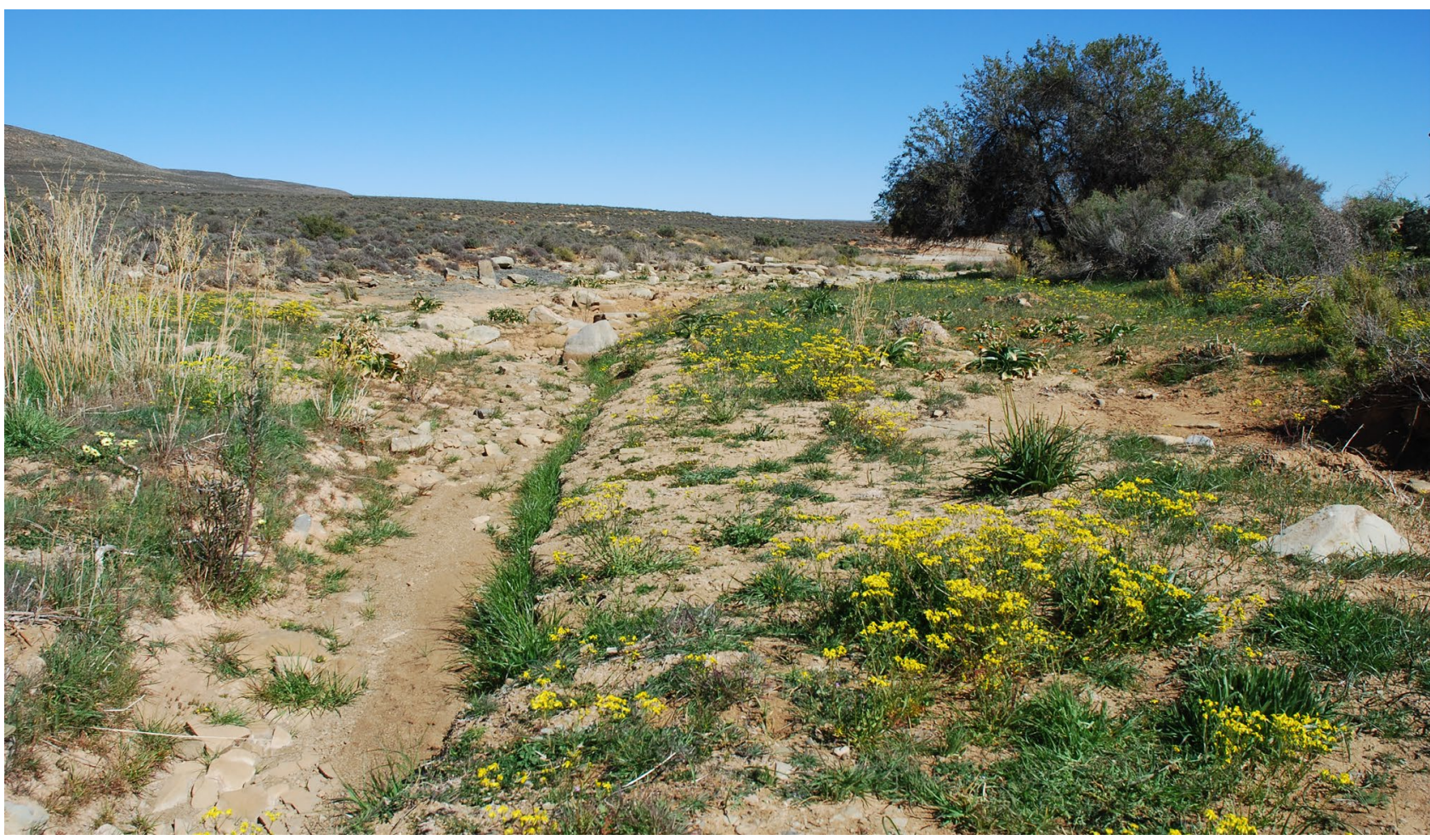

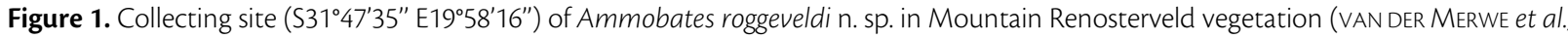
2008) along a dry river bed in the northern extension of the Hantam-Roggeveld Centre of plant endemism (CLARK et al., 2011), south of Calvinia, South Africa. Photo M. KUHLMANN (1 September 2017).

\section{TAXONOMY}

\section{Ammobates (Ammobates) roggeveldi n. sp.}

zooBank http://zoobank.org/AC6C9904-3E15-4CBC-83AD 48B6F0E3E89C

\section{Diagnosis}

The female can be most readily separated from the only other sub-Saharan Ammobates species by the metasomal terga entirely black to dark brown (figure $2 a$ ) (in A. auster in both sexes metasomal terga are at least partly bright orange to reddish orange). Medial apical emargination of S5 deep (figure 4b) (in A. auster shallow; see EARDLEY \& BROTHERS, 1997: 411, figure 103). Apical emargination of S6 about twice as broad as in A. auster and S6 laterally beset with a row of stout yellowish setae that are about as long as the width of $\mathrm{S} 6$ (figure 4b) (in A. auster as long or shorter than half of the width of S6; see EARDLEY \& BROTHERS, 1997: 411, figure 104).

The new species belongs to subgenus Ammobates s. str. based on the following characters (MICHENER, 2007): second submarginal crossvein distal to second recurrent vein, female T6 without median ridge (figure 4a), labrum about twice as long as its basal width (figure $2 \mathrm{c}$ ), clypeus strongly protuberant (figure $2 \mathrm{a}$ ) and body length $9.5 \mathrm{~mm}$ (species of the other two subgenera $<8.5 \mathrm{~mm}$ ).

\section{Description}

\section{- Female}

Total body length $9.5 \mathrm{~mm}$. Head wider than long (length $2.20 \mathrm{~mm}$, width $3.50 \mathrm{~mm}$, ratio l:w 0.63). Intertegular distance $2.60 \mathrm{~mm}$.
Sculpture. Head smooth and shiny, with dense small punctures separated by half puncture width or less (figure $2 b$ ). Labrum smooth and superficially shagreened with scattered punctures separated by $1-3$ times puncture width on disc and gradually more tightly packed until separated by less than puncture width towards its base (figure 2c). Mesosoma smooth and shiny, with small to medium punctures separated by 1-2 times puncture width less on mesoscutum, slightly more narrowly spaced on other parts. Mesoscutellum, postscutellum and propodeum rugoso-punctate. Metasoma with anteriorfacing surface of first metasomal tergum densely and finely punctuate, punctures separated by puncture width or less, punctures on apical depression gradually more dispersed and apical margin impunctate. Following terga with similar pattern (figure 3b). Metasomal tergum six medially coarsely rugoso-punctate (figure 4a). Metasomal sterna five and six as in figure $4 b$.

Coloration. Head black except dark reddish-brown on medial part of mandible. Antenna black (figure 2b, c). Mesosoma black. Tegula dark reddish-brown at outer margin. Legs black, except reddish-brown spot at outer apices of tibiae I and II, tarsi 3-5 dark to light brown. Membrane of forewing fuscous, hindwing more hyaline; veins dark blackish-brown (figure 2a). Metasomal terga black (figure 3b). Metasomal sterna black, except apical margins hyaline dark brown.

Pubescence. Pubescence silvery white. Head loosely covered with long erect setae. Labrum with scattered, erect, minute to short, simple setae. Mesosoma with 


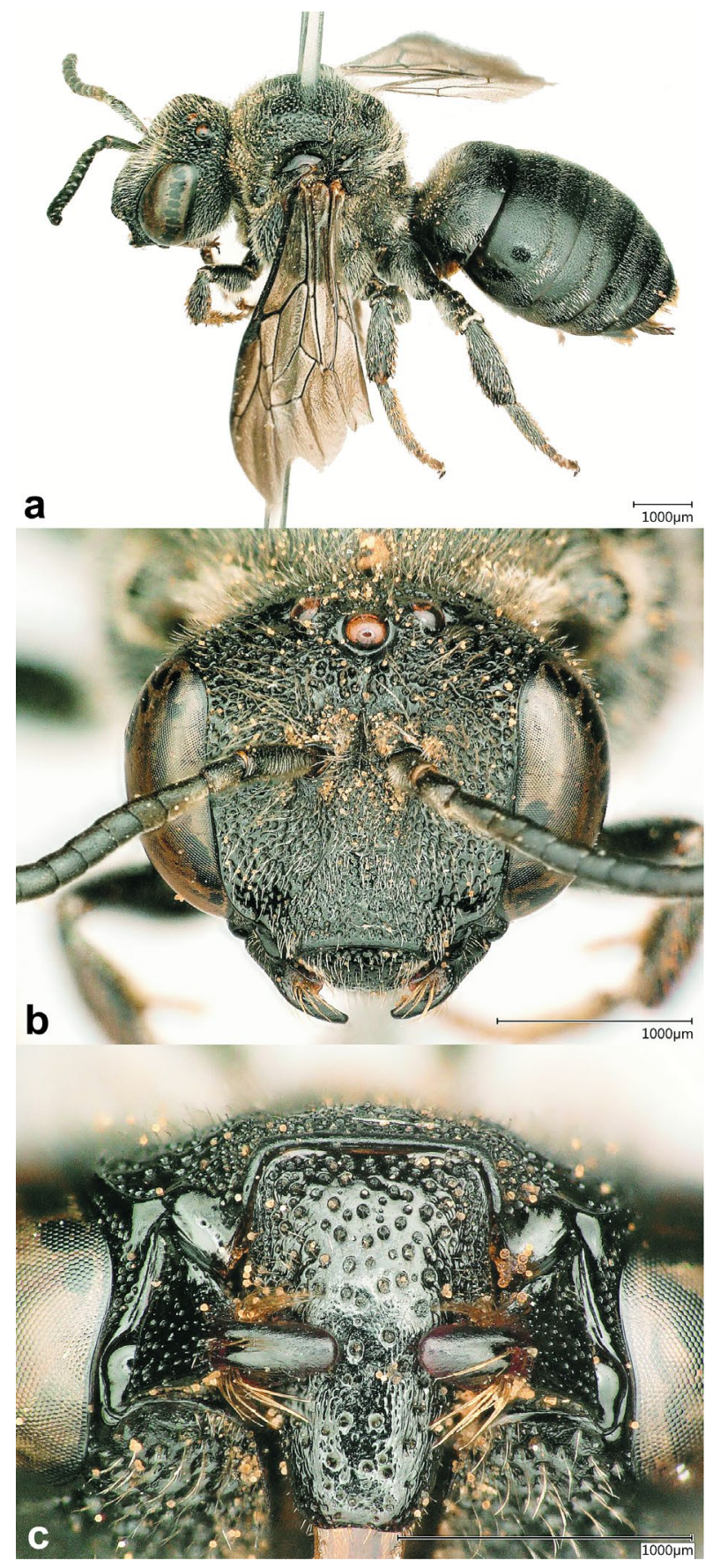

Figure 2. Female holotype of Ammobates roggeveldi n. sp. a. Lateral view. b. Head. c. Labrum and mandibles. Photos M. KUHLMANN.

pubescence similar to head except setae plumose and more densely covering this part of the body (figure 3a); posterior and lateral surface of propodeum laterally more densely covered with shorter suberect hair. Metasoma with scattered simple short subappressed to suberect setae (figure $3 \mathrm{~b}$ ); first metasomal tergum with scattered very short, erected, simple setae on disc, such setae dense laterally on dorsal-facing surface and plumose setae forming apicolateral hair patch; following terga with

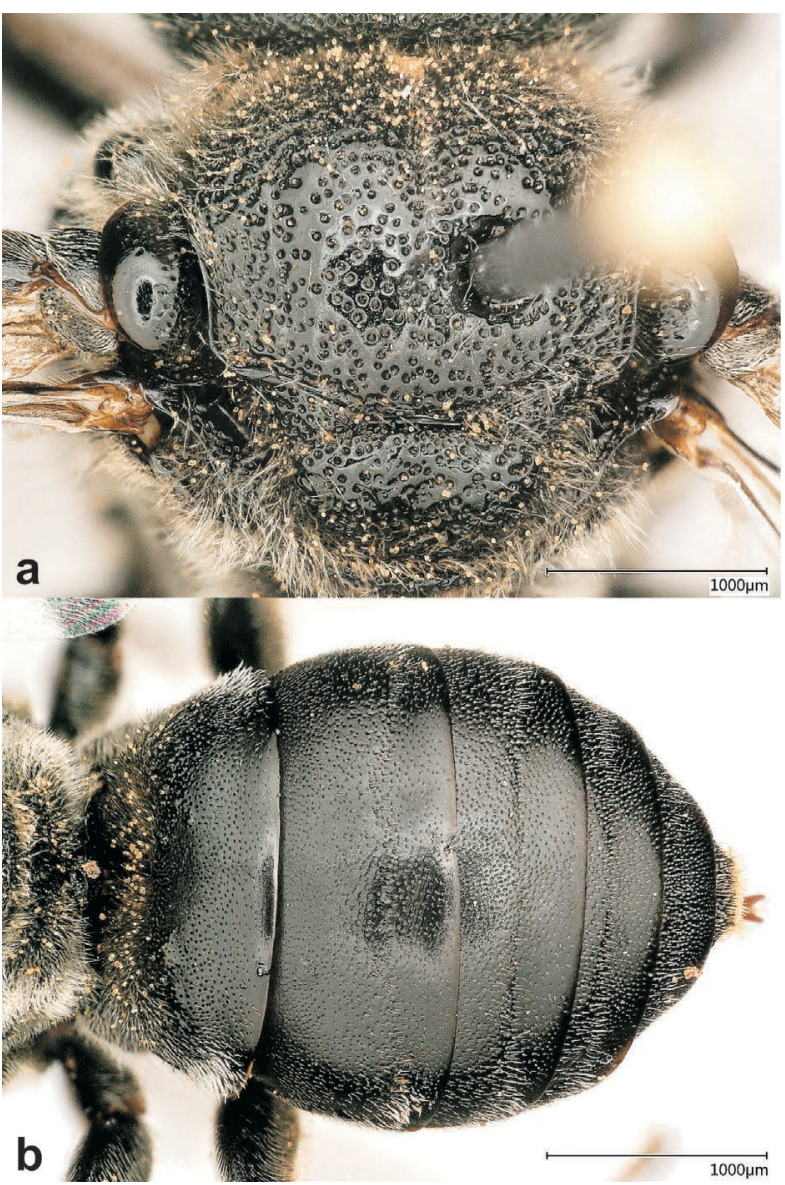

Figure 3. Female holotype of Ammobates roggeveldi n. sp. a. Scutum and scutellum. b. Metasoma (dorsal view). Photos M. KUHLMANN.

similar but less developed pilosity pattern (figure 3b); metasomal sterna with hardly visible scattered and short setae.

- Male

Unknown.

\section{Etymology}

The specific epithet refers to the Roggeveld Mountains where the species was found.

\section{Type material}

Holotype female "S.Afr., Roggeveld Mts., 2 km S Farm Perdekloof, rivier (= Afrikaans for river), dolerite, $\mathrm{S} 31^{\circ} 47^{\prime} 35^{\prime \prime}$ E1958'16", 1220 m, M. KuHLMANn leg. 2.Ix.2017" (SAMC).

\section{Key to females of sub-Saharan Ammobates species}

(Male of A. roggeveldi n. sp. unknown)

1. Metasomal terga at least partly orange to reddish orange A. auster EARDLEY, 1997

- Metasomal terga entirely black to dark brown A. roggeveldi n. sp. 

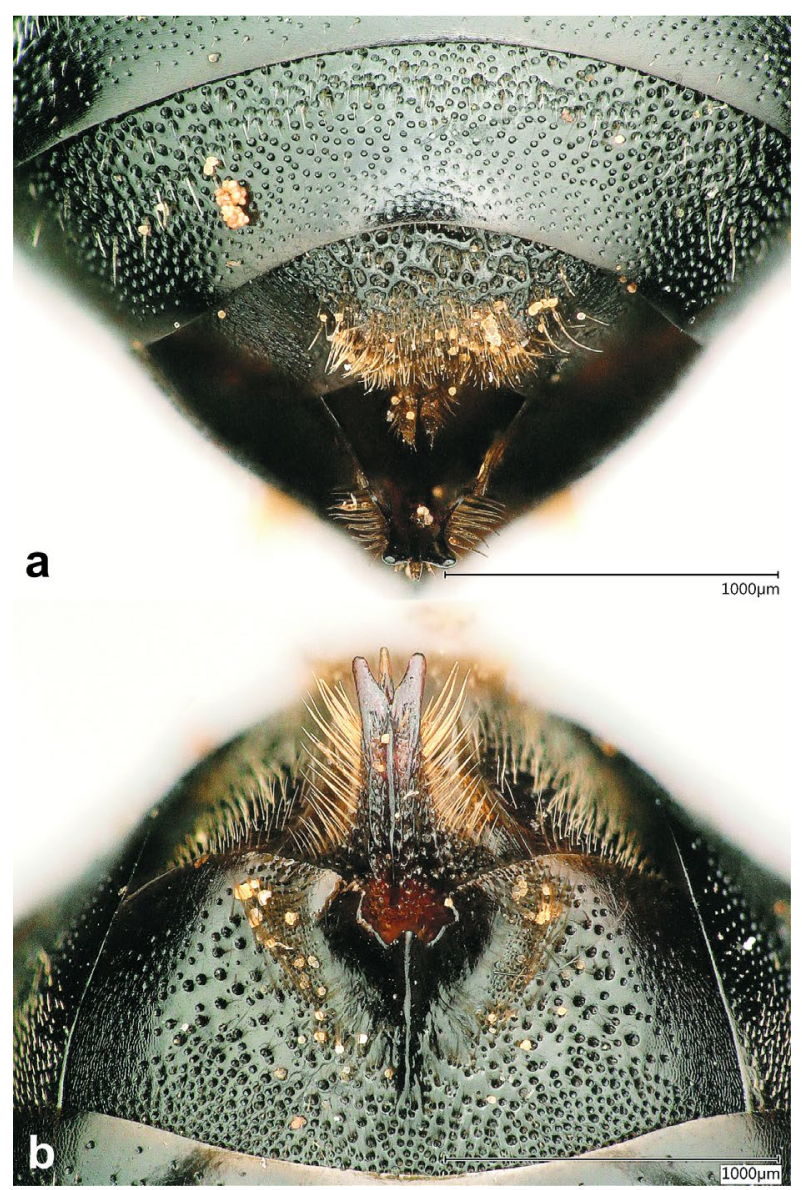

Figure 4. Female holotype of Ammobates roggeveldi $\mathrm{n}$. sp. a. Metasomal tergum T6. b. Metasomal sterna S5 and S6.

Photos M. KUHLMANN.

\section{DISCUSSION}

The record of a second Ammobates species in the southwest of the African continent underpins the outstanding biogeographic position of the GCFR as a center of wild bee diversity and endemism (KUHLMANN, $2005,2009)$. The region is particularly vulnerable to climate change induced range shifts of bees and their host plants which increase their risk of extinction (KUHLMANN et al., 2012).

Probable hosts of Ammobates species are Ancyla LEPELETIER DE SAINT-FARGEAU, Tetraloniella ASHMEAD and Anthophora LATREILLE (WARNCKE, 1983; MICHENER, 2007; ENGEL, 2009).
Species of the latter two genera can be locally abundant in the area and are the only suitable hosts with respect to their body size (KUHLMANN, unpubl.). However, the surprisingly few records of the two relatively large and conspicuous Ammobates species in southern Africa suggest that the unknown host(s) might be rare, too. The geographical spread of $A$. auster records ranging from the Namib Desert to Karoo and Fynbos biomes (EARDLEY \& BROTHERS, 1997) indicate that more than a single host species is likely used so the reasons for the rarity of the cleptoparasites remain unknown.

\section{ACKNOWLEDGMENTS}

The Department of Environment and Nature Conservation (Northern Cape Province, South Africa) is gratefully acknowledged for giving permission to collect bees. Special thanks to Benoît GESLIN (Marseille, France) for editing and reviewing as well as Petr BoGUSCH (Hradec Králové, Czech Republic) and Guillaume LEMOINE (Cambrai, France) for their reviews. 


\section{REFERENCES}

Born, J., H. P. LINDER \& P. Desmet (2007). The Greater Cape Floristic Region. Journal of Biogeography, 34(1): 147-162. https://doi.org/10.1111/j.1365-2699.2006.01595.x

Clark, V. R., N. P. BARKER \& L. MuCINA (2011). The Roggeveldberge Notes on a botanically hot area on a cold corner of the southern Great Escarpment, South Africa. South African Journal of Botany, 77(1): 112-126. https://doi.org/10.1016/j.sajb.2010.07.001

EARDLEY, C. D. \& D. J. BROTHERS (1997). Phylogeny of the Ammobatini and revision of the Afrotropical genera (Hymenoptera: Apidae: Nomadinae). Journal of Hymenoptera Research, 6(2): 353-418. https://www.biodiversitylibrary.org/page/4491805

ENGEL, M. S. (2009). Two new species of Ammobates from the Arabian Peninsula and Egypt (Hymenoptera: Apidae). Transactions of the Kansas Academy of Science, 112(3/4): 191-197. https://doi.org/10.1660/062.112.0406

KUHLMANN, M. (2005). Diversity, distribution patterns and endemism of southern African bees (Hymenoptera: Apoidea). pp. 167-172. In B. A. HUBER, B. J. SinCLAIR \& K.-H. LAMPE (ed.). African Biodiversity: Molecules, Organisms, Ecosystems. Proceedings of the 5th International Symposium on Tropical Biology, Museum Koenig, Springer Verlag, Berlin, 443 pp. https://doi.org/10.1007/0-387-24320-8_13

KUHLMANN, M. (2009). Patterns of diversity, endemism and distribution of bees (Insecta: Hymenoptera: Anthophila) in southern Africa. South African Journal of Botany, 75(4): 726-738. http://doi.org/10.1016/j.sajb.2009.06.016

KuhlmanN, M., D. Guo, R. VeldtMan \& J. Donaldion (2012) Consequences of warming up a hotspot: species range shifts within a centre of bee diversity. Diversity and Distributions, 18(9): 885-897. https://doi.org/10.1111/j.1472-4642.2011.00877.x

Linder, H. P., S. D. Johnson, M. Kuhlmann, C. A. Matthee, R. NyfFeler \& E. R. SWARTZ (2010). Biotic diversity in the Southern African winter-rainfall region. Current Opinion in Environmental Sustainability, 2(1-2): 109-116. https://doi.org/10.1016/j.cosust.2010.02.001

MiCHeNER, C. D. (2007). The bees of the world. 2nd edition. The John Hopkins University Press, Baltimore (MA, USA), xvi + [i] + 953 pp. +20 pls.

van deR Merwe, H., M. W. van Rooyen \& N. Van Rooyen (2008) Vegetation of the Hantam-Tanqua-Roggeveld subregion, South Africa. Part 1: Fynbos Biome related vegetation. Koedoe, 50(1): 6171. https://doi.org/10.4102/koedoe.v50i1.130

WARNCKE, K. (1983). Zur Kenntnis der Bienengattung Pasites Jurine, 1807, in der Westpaläarktis (Hymenoptera, Apidae, Nomadinae). Entomofauna, 4(21): 261-347.

https://www.zobodat.at/pdf/ENT_0004_0261-0347.pdf 
OSMIA est éditée par l'Observatoire des Abeilles (OA), une association loi 1901 d'apidologues (ou mellitologues) d'Europe francophone qui œeuvrent pour la connaissance et la protection des Abeilles sauvages.

Les articles sont:

publiés uniquement en ligne

- disponibles en open access.

- indexés / archivés par Crossref, Zoobank, HAL, Zenodo, OpenAIRE, Google Scholar et Web of Science (Clarivate) [Zoological Record],

- respectueux des recommandations de la Commission internationale de Nomenclature zoologique (ICZN)

- sous Licence Creative Commons Attribution International CC BY 4.0 qui autorise la reproduction et la diffusion du document, à condition d'en citer explicitement la source

- librement déposables sur des sites internet ou des plateformes d'archivage.

(!) Les documents d'autres sources et non distribuées sou licence libre sont reproduits après autorisation (à demander par les auteurs) et demeurent la propriété des auteurs ou éditeurs originaux.

(!) Le contenu publié est sous l'entière responsabilité des auteurs.

OSMIA est conçue pour une impression recto-verso en haute résolution. Les bibliothèques publiques, les laboratoires, les

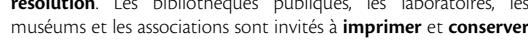
une version papier de la revue.
OSMIA is published by the Observatory of Bees (OA), a nonprofit society of apidologists (or mellitologists) from Frenchspeaking Europe who work together for the knowledge and protection of wild bees.

The items are

- published only online

- available in open access

- indexed / archived by Crossref, Zoobank, HAL, Zenodo, OpenAIRE, Google Scholar and Web of Science (Clarivate) [Zoological Record].

- respectful of the recommendations of the International Commission for Zoological Nomenclature (ICZN),

- under Creative Commons Attribution Licence International CC BY 4.0 which authorises the reproduction and distribution of the document, provided the source is explicitly cited, - freely depositable on personal or institutional websites and archiving platforms.

(!) Documents from other sources and not distributed under a free license are reproduced after authorisation (to be requested by the authors) and remain the property of the original authors or publishers.

(!) The published content is the sole responsibility of the authors.

OSMIA is designed for high-resolution printing on both sides. Public libraries, laboratories, museums, and societies are invited to print and keep a paper version of the journal.
Directeur de la publication • Editor-in-chief Benoît GESLIN

Comité éditorial • Editorial Board AUBERT • Floriane FLACHER • Mehdi ISSERTES. Tanguy JEAN • Léa LEMAIRE

Mise en page $\cdot$ Layout

Mehdi ISSERTES • Tanguy JEAN • Léa LEMAIRE

Comité de lecture • Scientific committee 2021

https://www.osmia-journal-hymenoptera.com/equipe-team.html

Soumission d'articles • Submission of items osmia.editor@gmail.com

Recommandations aux auteurs Recommendations to authors

https://wwwosmia-journal-hymenopteracom/auteurs-authorsinstructions.html

Observatoire des Abeilles 68 rea du Onze Novemes F - 59148 Flines-lez-Râches (France) https://oabeilles.net/

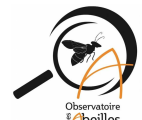

open (c) (C) 